\title{
Digitalisation Advances and Hospitality Service Encounters
}

\author{
Nathalie Montargot*
}

\begin{abstract}
A new hospitality concept gives more autonomy to the clients and mobility to the front-line employees. The objective of this research was to observe in situ the actors, customers and receptionists, operating in renewed lobbies. The research questions focus on how customers respond to the increased expectations of selfproduction and the way front-line employees adapt to their new roles. The review of literature highlights the importance of the service production process, its stages and customer integration in the innovative process. A study was conducted in a 4star pilot Parisian hotel affiliated to a major French hotel group. 490 nonparticipant observations, based on encounters of service were collected. The findings show the gap between the project's philosophy and the behavior of the actors on the ground. Managerial recommendations are presented.
\end{abstract}

Keywords: Digitalisation; Change Management; Hotel; Accor Group; Encounter of Service; Global Tourism; Global Markets

\section{Change Management in Hotel Competitive Industry}

The boundaries between production, consumption and customer collaboration have been blurring for some time (Bendapudi \& Leone, 2003; Neuhofer et al., 2014). The customer now performs some of the work, as a self-directed autoproduction and takes responsibility in partly automated, simplified tasks (Dujarier 2008). Therefore, "the advent of a user-generated content movement, the diffusion of social media and Web 2.0 technologies, and the emergence of skilled and well-educated customers have enabled whole crowds or single users to heavily collaborate in the production processes of companies" (Pironti et al., 2015, p. 29). This new workload can be seen in some cases as a double exploitation (Cova \& Dalli, 2009).

Marketing management "presupposes understanding of demand (and above all of its segments), in order to offer a product that can fill a given space on the market" (Brondoni, 2009). Consequently, a company must in a strained competitive environment, reflect changes in consumption patterns and develop a digital strategy, which affects both its offerings and delivery of service. The literature shows that intangible corporate assets, so important in the hotel industry the focus

\footnotetext{
* Associate Professor, CEREGE Poitiers, Essec Chair of Change, Groupe Sup de Co La Rochelle (montargotn@esc-larochelle.fr)
} 
of this research "are linked to the creation and consolidation of a specific organisation culture, the design and management of the company information system, and finally the creation and development of a specific brand equity" (Brondoni, 2009). Therefore, new technologies, included in these assets, have the benefit of reducing costs and errors (Chathoth, 2006), increasing satisfaction and customer loyalty, and making possible an expansion of its target markets (Bitner et al., 2002).

Design is a key business asset linked to business performance (Kristensen \& Gronhaug, 2007). The hotel industry has experienced unprecedented change and this has led large groups, such as Marriott, Starwood, Intercontinental, Hilton and Accor to rethink their operations by designing a new physical environment that favours autonomy of the client (Kasavana \& Connolly, 2005). Now a customer who books on the Internet is able to check-in via its computer, mobile phone or other devices. On the day of their arrival, he/she receives an e-mail or text message telling his/her room number and a code to obtain the key in a self-service kiosk located inside the hotel. The objective of this research was to observe in situ the actors operating in lobbies. The research questions focus on how customers respond to the increased expectations of self-production and the way front-line employees adapt to their new roles. In section 1, the review of the extant literature will highlight the importance of the service production process, its stages and customer integration in the innovative process. The context of the study, its methodology will be specified in section 2. The main results of a study based on 490 non-participant observations, during two key moments of the customer's stay: arrival (check-in) and departure (check-out), conducted between March and April 2014 in a Parisian 4-star hotel belonging to a major French hotel group will be presented in section 3. Finally, section 4, the discussion will highlight our improved understanding of critical points during the service encounter. Managerial recommendations will be presented in section 5 .

\section{The Role of the Customer During the Service Production Process}

"The first imperative for global corporations is, indeed, to deliver value to empowered customers" (Brondoni \& Pironti, 2015). Pine and Gilmore (1998) also asserted the importance of customer experience, which goes beyond offering customers unique, memorable and economically valued experiences. These contextual experiences reflect emotional responses to a stimulus during the service delivery. Organizations seek to control and manage their customers' experience and emotions. Consequently, the process of service (1.1), its staging (1.2) and the appropriation of new technologies by the client (1.3) deeply influence the transaction.

\subsection{The Process at the Heart of the Service Encounter}

"In a business mode, the transactional and relational dimensions of the business model are depicted as fundamental" (Pironti et al., 2015, p. 28). The degree of contact between staff and customers is at the heart of the service process and depends on the level of respective participation during the encounter of service 
(Eiglier \& Langeard, 1987). In the context of customer relationship management, high-end hotels seem to adopt a situational, even emotional approach to the service encounter (Codello-Guijarro et al., 2011). In this respect, the literature suggests a need to strengthen the front office skills, to increase the proximity between customers and front-line employees (Mechinda \& Patterson, 2011).

The central elements of the service process are specified in the literature:

- The client (assessor and co-creating actor of the consumption experience (Vargo \& Lusch, 2004; Goudarzi \& Eiglier, 2006);

- employee, whose challenge is to manage the service encounter and satisfy informed and demanding customers (Berry et al. 1994).

- The information system that should be designed to facilitate transactions between customers and staff. Therefore, the elements (e.g. furniture and equipment) for carrying out the service must be a judicious choice.

"Interacting effectively with customers in the digital era has implications beyond marketing products and services" (Brondoni \& Pironti, 2015, p. 9). In a hotel, the lobby, place of social interactions, is the central place of the transactions of service, between front-line employees and customers. It is therefore important to analyze the environment in which the client will take place.

\subsection{The Visible Part of the Service for the Customer: The Servicescape Model}

To improve service and put forward the offer, the staging is crucial. This is the space where interaction takes place, staged spaces designed for customers are planned, organized and optimized. Thus, the context and the environment, influence consumer perception. Physical surrounding also named 'Servicescape' (Bitner, 1992) are designed by service organizations to assess the difference in customer experience and facilitate the provision of service offerings to customers. Figure 1 shows Bitner's Serviscape Model with emphasis on physical environmental dimensions and its involvement on cognitive, emotional and psychological responses, both for the customer and the front-line employee (Bitner, 1992).

The Servicescape matches perfectly, when customer behavior is in line with organizational expectations. In case of deviance, service staff will face inappropriate behaviors from the customer, which may cause tension. Managing the client role during the process is therefore crucial.

\subsection{The Integration of the Customer in the Process}

The client performs functions formerly carried out by the organization. S/he becomes co-producer (Eiglier \& Langeard, 1987), co-creator (Prahalad \& Ramaswamy, 2000, 2004; Vargo \& Lusch, 2004) or contributor (Dujarier, 2008). Digital technologies provide opportunities for change that require players to redefine their roles and interactions and lead them to experiment with new modes of operation, organization and governance. Technology becomes the pretext, the means and the media to make sense (Swanson \& Ramiller, 1997).

To encourage customer's participation in innovative experiments, the organization can act on different levers: communication, explanation and 
development of expected benefits, and proposal for an outstanding experience through customer suggestions. The acceptance of digital change is dependent on how individuals and organizations, understand the issues related to new technologies (strengths, benefits, risks, opportunities) and how they react (positively or negatively).

All or part of the customer/front-line employee encounter is being dematerialized. The trend is to the implementation of Self-Service Technologies (SSTs) (Meuter et al., 2000) using interfaces, off-line or on-line, and offering various methods (touchscreens, voice recognition, etc.) (Mencarelli \& Rivière, 2014). Thus, smartphones and tablets are now playing an important role in the relational space, without any constraint of language. It is possible to listen to music, take pictures, consult hotel facilities, contact the concierge, book a table at the restaurant or ask for room service, without any personal exchange.

Figure 1: Bitner's Servicescape Model (1992)

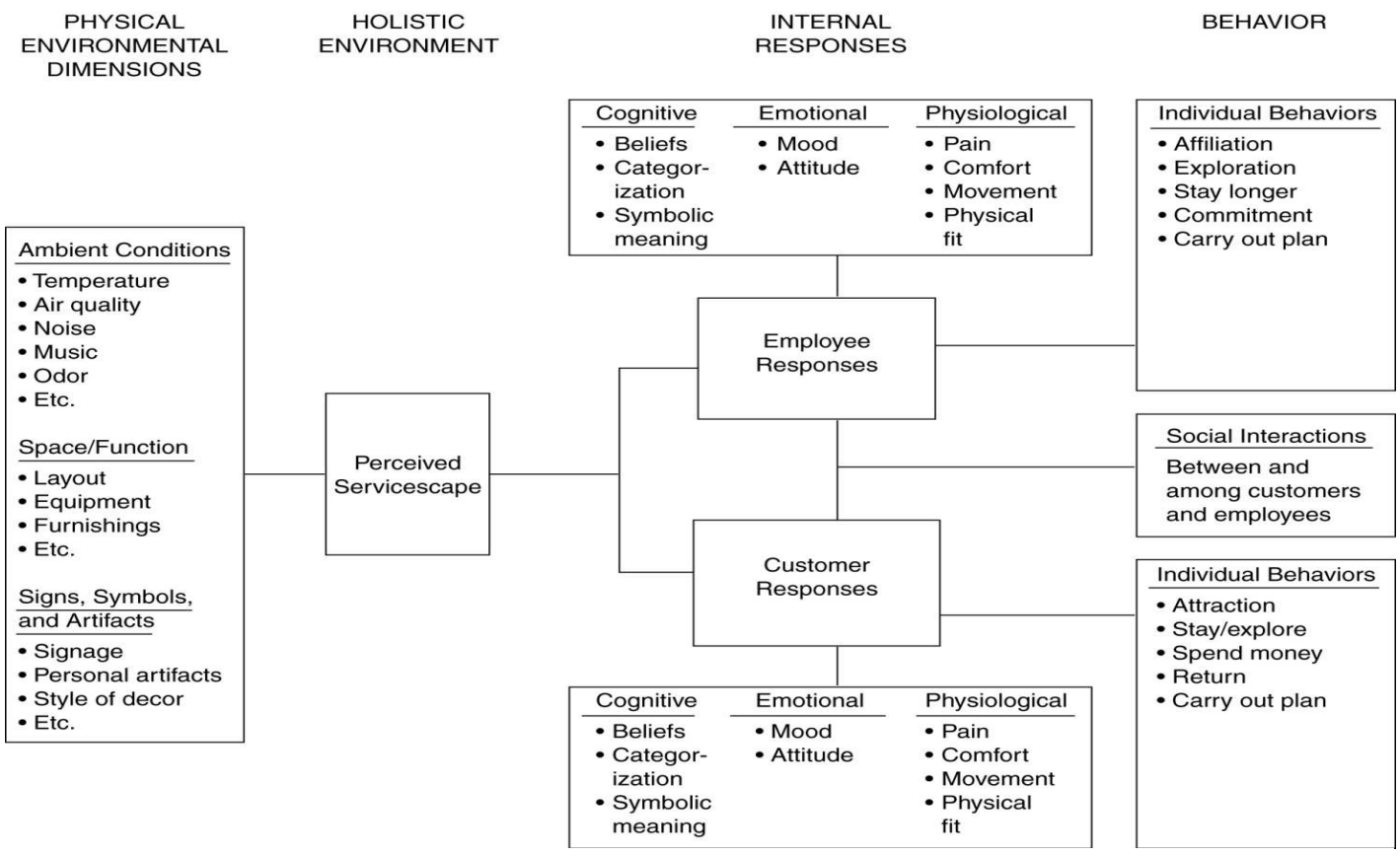

Source: Bitner (1992)

\section{The Empirical Study}

The current study, conducted in a 4-star pilot Parisian hotel seeks to capture service transactions, in times of digitalization change, experimentally implemented by a major French hotel group. Favoring a quantitative methodology, data was collected from standardized non-participant observations, after a phase of floating observations. These observations led to the analysis of 490 encounters of service over a period of four weeks, between March and April 2014. The context (2.1) and methodology (2.2) are now explained. 


\subsection{The Context}

The Accor Group, leader in Europe, is present in 92 countries with nearly 3,500 hotels and 450,000 rooms. Its portfolio includes products ranging from economy (Formule 1, Ibis) to middle range (Novotel, Mercure), high range (Pullman) and luxury (Sofitel). The focus of this research is on the development of the "Welcome" program. For a better understanding of the concept, a secondary data analysis (press articles, annual reports of the group) and an interview with the Vice-President of Consumer Technology (now identified as VPCT) were conducted.

The "Welcome" project is defined as a new hospitality concept around the service encounter between more autonomous clients and mobile front-line employees. The philosophy of the project emphasizes the versatility of places and multitasking functions of the front-line employees, now called "Welcomers". Therefore, "Technology is just a medium, a way to differentiate itself, it remains a medium of communication and customer experience. Today, the entire operational process is reconsidered" (VPCT). This is to remove the technical and physical barriers to return to the heart of the hospitality business "all hotel functions that were related to the direct customer have been redesigned" (VPCT). Consequently, it is not the customer who goes to the reception, but it is the reception staff that comes to meet the customer as soon as s/he enters the lobby.

The Mercury brand was preferred for the project. It operates $75 \%$ under the franchisee and $25 \%$ by management mandate. It is positioned in the mid-range and focuses on customizing hospitality. It includes 758 hotels worldwide (Accor, 2014). A new design of the public space "has been tested in a London hotel in 2013 and then in 14 pilot units worldwide in 2014" (VPCT). The project has led to a new design of public spaces: (i) a single host public space (reception desk - lobby business center - relaxation area - fast food vending machines $24 \mathrm{~h} / 24 \mathrm{~h}$ ) without wall units reduces the distance between contact personnel and the customer. The whole lobby has become a workspace for Welcomers. (ii) counters (desk) shared by the contact personnel and customers that offer a different style, with three possible service experiences (express, friendly and cozy). The check-in and out zones, are now chosen by the customer without distinction between privileged customers or not. Meanwhile, the receptionist function has been redesigned and more flexibility has been introduced.

\subsection{Methodology}

The research was conducted by observing customers and front-line employees' behaviors when the service encounter occurred (David et al. 2000). Prior to this, two exploratory interviews were conducted with the General Manager and the Front-office manager, six months after the implementation of the Welcome project. During those months, the staff had been involved and trained in their new roles. The procedures used during check in and check out have been studied.

Regarding the lobby, several areas of service encounter were identified:

- The reception desk was modernized, but was smaller than a usual front-desk.

- Different furnished spaces that can be used during the service encounter (host tables, consoles). 
- The rest of the lobby for a completely nomadic use, without any furniture items.

An observation grid based on the movements in the lobby and the behavior of actors was established. Thus, the encounter of actors, their behavior, the choice of transaction spaces and their progress (duration, observed behavior and procedural content) were systematically recorded. The slots were chosen according to the most significant flow of customers, during check-out (18h-20h) and check-in times (7h30-9h30). A total of 20 slots were defined with four trained observers documenting 490 encounters. The data were processed and analyzed using Excel.

\section{Results: Spatial Analysis According to the Areas of the Service Encounters}

$76 \%$ of the observed clientele came from the business segment, $81 \%$ male and $74 \%$ were between 35 and 54 years old. Having clarified the customer profile, the results concerning the two key moments of their stay: arrival (3.1) and departure (3.2) will be discussed.

\subsection{Arrival}

The consumer must have analysed and understood the offer, moves towards various reception spaces. We observe that it is the customer who is going to meet the Welcomer and not the contrary, as advocated by the new philosophy of the concept. In $60 \%$ of the observations 1 to 4 customers occupy the lobby. Different behaviors were observed. Customers appeared passive and disoriented when the lobby had less than five clients. However, when the flow is more obvious, signs of disorientation are reduced but signs of impatience appear more quickly. Concerning the waiting time, on average $70 \%$ of customers are engaged by a Welcomer in less than 30 seconds. However, the $3 \%$ of clients waiting three minutes or more exhibit increasing signs of impatience. Regarding the occupation of space, $49 \%$ of checkins were at the reception desk, while $29 \%$ of check-ins took place in a support zone and $22 \%$ outside in furnished spaces in a very nomadic mode.

It was observed that the furnished zones are preferred. More than three out of four customers favor a service encounter that involved a physical barrier, even a symbolic one. Whatever the flow of customers and the attendance in the hall were, more than two out of three customers moved systematically and spontaneously to a physical element. A minority adopted a completely nomadic concept prescribed by the project 'Welcome'.

Clients, in the different service encounters places, expressed their emotions differently. Thus, at the desk, $40 \%$ acquiesce and amplify signs of positive or negative emotion. $57 \%$ were smiling but $9 \%$ showed signs of nervousness, twice that in the nomad zone and $34 \%$ showed no emotion at all. For front-line employees, the administrative relationships are still a priority. Despite the new philosophy of the project, the transactions mostly revolved around administrative issues, and left little opportunity for relationship building. $97 \%$ of customers did not ask any questions during the check-in and were passive during the encounter. For their parts, Welcomers did not engage in the booking elements. Three out of four 
did not control the number of beds room type number of people or invoice elements when the transactions were booked through a company or agency

Commercial functions, however they are put forward by the group are in the background, e.g. application to the membership loyalty program, the services available in the hotel or the quality program. The commercial role of Welcomers is still not fully developed despite the new orientation.

\subsection{Departure}

During check-out, the transaction was faster despite unnecessary control elements, as the nomadic zone increases customer satisfaction. At the time of his arrival in the lobby, $44 \%$ of customers found their own way and $43 \%$ went to an employee. Regarding geographical distribution, in $47 \%$ of cases, the transaction took place at the desk, compared to $39 \%$ in a support zone and $14 \%$ in a nomadic way (a decrease of 8 points comparing to the check-in period). The furnished zones seem to be more popular during this phase. The customers did not adhere to the philosophy of the concept.

We noticed that the transaction duration got significantly faster $(72 \%$ in less than three minutes against $47 \%$ of check-in). However, it increased substantially both in furnished zones and the desk (77\% and $73 \%$ of transactions completed in less than three minutes). Therefore, the customer was always looking for a separation between front-line employees and themselves.

Some elements slowed down the process. They correspond to control operations about additional services (extras) or billing. One client out of two still demanded a paper invoice, when they had the opportunity to receive it instantly electronically. Therefore, the duration of the check-out increased significantly.

\section{Discussion}

The findings suggest that the gap between the project's philosophy and the behavior of the actors on the ground, requires managerial adjustments. The involvement of the client in the process of service delivery system must firstly be strengthened through appropriate customer education (3.1) and a better training of the front-line employees (3.2).

\subsection{Facilitating the New Role Assigned to the Customer}

During the service encounter, the customer can be considered a co-producer (Eiglier \& Langeard, 1987; Bendapudi \& Leone, 2003), a co-creator of value (Vargo \& Lusch, 2004) or even a collaborator (Bowen 1986; Mills \& Morris, 1986; Schneider \& Bowen, 1995; Cova \& Cova, 2009). Indeed, they contribute to the quality of service and their own satisfaction, but also create value during their interactions with the physical and social elements of the service. Such elements affect behavioral, emotional, cognitive and social responses.

Accordingly, it seems important to integrate the client's role, as a new collaborator in the organization, and to facilitate the customer's understanding of this new role. A transitional learning period is required, during which the client 
must be over-assisted. Staff will therefore have to be careful during this time and be proactive. They should inform, assist, guide and encourage the client to develop more autonomy during this critical phase.

The current study shows that different factors negatively affect customer participation. These include the prioritization given by front-line employees to the administrative aspect of their tasks and the negative aspects of interpersonal and commercial relationships, such as a lack of upstream preparation concerning customer booking elements (e.g. no systematic key encoding).

Therefore, during their stay a customer's education should include explanatory elements of the organization's functioning in order to highlight the benefits that customers can expect. This education can occur at two stages of the relationship with the organization, i.e. before the service (access to mobile apps) and during the service (use of check-in terminals, e-concierge). It can be assessed during or after the stay by the collection of quality information, encouragement to give opinions and the sharing of on-line reviews.

\subsection{A Better Compliance of Front-Line Employees to the New Rules}

Staff must fully adhere to a new service philosophy to ensure success (Ford et al., 2008). Front-line managers and back-office managers, must, in all circumstances, prioritize the front-line employees comfort and place them in the best physical and psychological conditions, so that they will be able to influence positively the quality of service delivered. This should limit negative interactions between frontline employees and customers, in order to reduce conflicts.

Staff must be convinced of the importance of developing relationships with customers and making an effort to satisfy them. We found that the customer service encounter mainly takes place in furnished zones with visible separators, e.g. counter, tables and physical support.

Especially in times of change, employees must control their own emotional reactions and control those of the clients, even though the spatial distance is reduced. Proper training can help them (Nasse \& Legeron, 2008) to control stressful situations and reduce their negative impacts on well-being (Bruchon-Schweitzer et al., 2006). Moreover, they would develop new skills and attitudes that promote cocreation of value with customers. Management must regularly review how frontline employees play these roles to avoid standardization or boredom.

On the other hand, simulating unfelt emotions (Grandey et al., 2005) can lower the quality of service (Hochschild, 1983). It is therefore necessary to organize exchange moments in real-life situations and possible improvements (support groups, meetings) in order to encourage professional exchanges. Management need strategies for collecting information that encourage staff participation (Ford et al. 2008).

We advocate for a better clarity of the roles, so that the client understands his new role and adopts a co-production behavior in accordance with the organizational requirements (Meuter et al., 2005; Larson \& Bowen, 1989; Mills \& Morris, 1986; Rizzo et al., 1970). 


\section{Conclusion and Emerging Issues}

Service innovation is based on the creation of new elements and on the coproduction process. This research allowed in situ observations digitized service and studying the behavior of actors in a new spatial environment. Theoretically, the results confirm the relevance of the holistic approach to set design of a hotel lobby for a better understanding of both the behaviors of customers and front-line employees. At a managerial level, this research identifies the challenges that the organization faces in its implementation of a new philosophy of digitalized service. We recall, however, that if the consumer saves time, procedural effectiveness evolves towards a reduction in social encounters (Codello-Guijarro et al., 2011). Other research methods and associated analysis would address the issues of digital change perceived by the actors. As this study uses a limited dataset, a combination of qualitative and quantitative research covering all elements of the staging of the service would be relevant.

The digitalization of the front-office functions as prescribed by the Accor group is a first step. Other avenues of research may consist in studying the effects of a more advanced form of digitalization with no contact at all with the staff, during a stay. We know the importance for global corporations to achieve "a differential advantage in terms of product design therefore means designing an offer based on the best interpretation of corporate imitation and innovation processes" (Brondoni \& Pironti, 2015). In this regard, the case for instance of the Hilton hotels is interesting. Actually, the chain announced the modernization of 4,000 of its hotels, and invested $\$ 550$ million for the use of smartphones, via a dedicated application, it is possible to book a room and proceed to check-in without coming to the reception desk. Electronic locks will be installed on each door. Customers only have to consult the previously sent code on their smartphone to access. They can also receive notifications informing them of commercial operations. A way to rethink more radically the process of service, for an industry that fully enters in a collaborative era (Cova \& Cova, 2009).

\section{Bibliography}

Bendapudi, N., \& Leone, R.P. (2003). Psychological implications of customer participation in coproduction. Journal of Marketing, 67, (1), 14-28.

Berry, L. L., Zeithaml, V. A., \& Parasuraman, A. (1994). Five imperatives for improving service quality. MIT Sloan Management Review, 31(4).

Bitner, MJ. (1992). Servicescapes: The Impact of Physical Surrounding on Customers and Employees. Journal of marketing, 56 (2), 57-71.

Brondoni, S. M. (2002). Global Markets and Market-Space Competition. Symphonya. Emerging Issues in Management (www.unimib.it/symphonya), (1), 7-15.

http://dx.doi.org/10.4468/2002.1.02brondoni

Brondoni S. M., (2009). Market-Driven Management, Competitive Customer Value and Global Networks, Symphonya. Emerging Issues in Management (symphonya.unimib.it), (1), 8-25 http://dx.doi.org/10.4468/2009.1.02brondoni

Brondoni, S.M., \& Pironti, M. (2015). Ouverture de 'Design Management, Product Engineering and Global Competition', Symphonya. Emerging Issues in Management, (2). 
http://dx.doi.org/10.4468/2015.2.01ouverture

Bruchon-Schweitzer, M., \& Rascle, N. (2006). Le burnout et la santé, in El Akremi, Guerrero et Neveu, (eds) Comportement organisationnel : épuisement professionnel, justice organisationnelle et difficultés de carrière, Editions De Boeck.

Chathoth, P. K. (2006). The impact of information technology on hotel operations, service management and transaction costs: A conceptual framework for full-service hotels firms. International Journal of Hospitality Management, 26 (2), 395-408.

Cova, B., \& Cova, V. (2009). Les figures du nouveau consommateur : une genèse de la gouvernementalité du consommateur. Recherche et Applications en Marketing, 24, (3), 81-100.

Cova, B., \& Dalli, D. (2009). Working consumers: The next step in marketing theory?. Marketing Theory, 9, (3), 315-339.

Cova, V., \& Giannelloni, J.L. (2010). Vers une approche de l'hospitalité au travers d'une mesure du concept de «Chez-soi ». Etapes préliminaires. Actes des 9èmes Journées Normandes de Recherche sur la Consommation, IAE Rouen et Rouen Business School, Rouen, 25-26 mars.

David, A., Hatchuel, A., \& Laufer, R. (2000). Les nouvelles fondations des sciences de gestion. Presses des Mines.

Dujarier, M.A. (2008). Le travail du consommateur. De McDo à eBay : comment nous coproduisons ce que nous achetons. Paris, La Découverte.

Eiglier, P., \& Langeard, E. (1987). Servuction. Le marketing des services. Paris, McGraw-Hill.

Ford, R., Heisler, W., \& Mccreary, W. (2008). Leading change with the 5-P model. Cornell Hospitality Quarterly, 49 (2), 191-205.

Goudarzi, K., \& Eiglier, P. (2006). La socialisation organisationnelle du client dans les entreprises de service : concept et dimensions. Recherche et Application en Marketing. 21, (3), 65-90.

Grandey, A.A., Fisk, G.M., Mattila, A.S., Jansen, K.J., \& Sideman, L.A. (2005). Is "service with a smile" enough? Authenticity of positive displays during service encounters. Organizational Behavior and Human Decision Processes, 96, (1), 38-55.

Hochschild, A. (1983). The managed Heart. Berkeley. University of California Press.

Kasavana, M. L., \& Connolly, D. J. (2005). Self-service kiosks: Hotels expand guest services. The Bottomline, (20), 14-17.

Kristensen, T., \& Gronhaug, K. (2007). Editorial Essay: Can Design Improve The Performance Of Marketing Management?, Journal Of Marketing Management, 23, (9-10), 815-827.

Larson, R., \& Bowen, D. E. (1989). Organization and customer: Managing design and coordination of service, Academy of Management Review, (14), 213-233.

Lin, Y. (2004). Evaluating a servicescape: the effect of cognition and emotion, Hospitality Management. (23), 163-178.

Mencarelli, R., \& Riviere, A. (2014). La participation du client dans un contexte de self-service technologies, Revue Française de Gestion. 40, (241), 13-30.

Meuter, M.L., Bitner, M.J., Ostrom, A.L., \& Brown, S.W. (2005). Choosing among alternative service delivery modes: an investigation of customer trial of self-service technologies. Journal of Marketing, 69, (2), 61-83.

Meuter, M.L., Ostrom, A.L., Bitner, J.M., \& Roundtree, R. (2003). The influence of technology anxiety on consumer use and experiences with self-service technologies. Journal of Business Research, 56, (11), 899-906.

Mills, P. K., \& Morris, J. H. (1986). Clients as partial employees of service organizations: Role development in client participation. Academy of Management Review, (11), 726-735.

Nasse, P., \& Legeron, P. (2008). La détermination, la mesure et le suivi des risques psychosociaux. Rapport remis au ministre du Travail. Paris : Ministère du Travail.

Neuhofer, B., Buhalis, D., \& Ladkin, A. (2014). Co-creation Through Technology: Dimensions of Social Connectedness. Information and Communication Technologies in Tourism, Springer International Publishing, 339-352.

Pironti, M., Cautela, C., \& Christodoulou, J. (2015). Business Models Innovation through New Customer Roles: A Design-Driven Case Study. Symphonia. Emerging Issues in Management, (2). 
Rizzo, J. R., House, R. J., \& Lirtzman, S. I. (1970). Role conflict and ambiguity in complex organizations. Administrative Science Quarterly, (15), 150-163.

Rouquet, A., Reniou, F., \& Gourdazi, K. (2013). Le client « acteur » de l'organisation, Enjeux et perspectives pour les sciences de gestion. Revue française de gestion, (234), 85 -98

Russell, J.A. (2003). Core affect and the psychological construction of emotion. Psychological review, 110(1), 145-172.

Shostack, G.L. (1992). Understanding services through blueprinting. Advances in Services Marketing and Management, 1, (1), 75-90.

Swanson, E. B., \& Ramiller, N.C. (1997). The Organizing Vision in Information Systems Innovation. Organization Science, (8), 458-474.

Vargo, S.L., \& Lusch, R.F. (2008). Service dominant logic: continuing the evolution. Journal of the Academy of Marketing Science, vol.36, (1), 1-10. 